\title{
乳頭状ならびに非乳頭状移行上皮癌の細胞構築
}

\author{
秋田大学医学部泌尿器科学教室（主任：土田正義教授） \\ 守山正胤
}

\section{CELLULAR ARCHITECTURE OF PAPILLARY AND NONPAPILLARY TRANSITIONAL CELL CARCINOMA}

\author{
Masatsugu Moriyama \\ Department of Urology, Akita University, School of Medicine \\ (Director: Prof. S. Tsuchida)
}

To characterize the cellular architecture of papillary and nonpapillary transitional cell carcinoma. 2 normal ureters, 6 papillary bladder cancers and 5 nonpapillary bladder cancers were subjected to light and electron microscopic study as well as three dimensional reconstruction by $0.5 \mu \mathrm{m}$ thick serial sections.

Normal urothelium consisted of three cell layers of the basal, intermediate and superficial cells, each of which was morphologically characterized in terms of cell shape and development of cell organelles. Over $90 \%$ of the epithelial cells were proved to be connected to the uniform basement membrane directly or with long, fine cytoplasmic processes, forming hemidesmosomes at the junctional portion.

Papillary tumors had, as a rule, the same cellular architecture as that of normal epithelium in terms of the regularity of cellular polarity, arrangement and differentiation, and the connection to the basement menbrane. But, in G2 tumors, the connection between the intermediate and superficial cells and the basement membrane failued to be confirmed in 7 to $44 \%$ of the cells, suggesting the heterogeneity of the tumors.

In contrast, nonpapillary tumors showed a high irregularity of the cellular architecture in both lesions of stromal and intra-epithelial invasion. The development of the basement membrane was indefinite, often showing thinning or disruption where occasional cytoplasmic protrusion of the tumor cells into the lamina propria was found. Nearly all of the intermediate and superficial cells in the intraepithelial lesions proved not to communicate with the basement membrane.

The present results indicate distinct differences of cellular architecture between the papillary and nonpapillary urothelial tumors. which may reflect not only the growth pattern but also the biological behaviour of the individual tumors.

キーワード：細胞構築, 移行上皮, 移行上皮癌

要旨: 乳頭状移行上皮癌と非乳頭状移行上皮癌の細胞構築を明らかにするために, 正常尿管 2 例, 乳頭 状癌 6 例ならびに非乳頭状癌 5 例について, 細胞形態の分化, 基底膜との関係ならびに基底膜の形態を, 光顕，電顕ならびに連続切片法を用いた 3 次元的再構築によって検索した。

正常上皮では, 基底細胞が細胞内小器官の発達を伴って, 中間ならびに表層細胞への規則正しい分化 を示し, 約 $90 \%$ の表層ならびに中間細胞は細胞突起で基底膜と直接連絡しているのが確認された. 乳頭 状癌では, 基本的には正常上皮と同様に極性は保たれ，基底細胞が基底膜との連絡を保ったまま，しだ いに中間ならびに表層細胞へ分化する傾向が認められた。しかし，G2乳頭状癌の 1 例では, 中間あるい は表層細胞の 7 ４4\%で基底膜との連絡を確認できず，G2腫場の heterogeneity を示すものと考えられ た. 
一方，非乳頭状癌では，浸潤部分のみならず，上皮内伸展部分でも細胞の極性は失われ，規則的な細 胞分化はみられず，かつ，基底膜と連絡をもつ細胞も確認できなかった。 また基底膜の発達も不完全で， しばしば菲薄化ないしは断裂しており, 微小突起が断裂部より粘膜固有層へ侵入していた.

上述の如き乳頭状癌と非乳頭状癌の細胞構築の違いは, 両者の発育様式のみならず, 生物学的悪性度 の差として反映されると考光られた。

\section{緒言}

尿路移行上皮癌は発育様式から乳頭状癌と非乳頭状 癌に大別される11。一般に前者はlow grade かつ low stage にとどあるのに対し，後者は high gradeであり high stage に移行しやすいとされ，両者の悪性度は対 照的である233. 一方，正常移行上皮は細胞突起をるっ て基底膜との連絡を保ちつつ，基底細胞から，中間細 胞さらに表層細胞一と分化するといわれている(4) 9). 当然のことながら，このような正常上皮に特徽的な細 胞構築は癌化によって何らかの修飾をうけ，その結果 が発育様式に反映すると思われる。

以上の観点から, 本研究では乳頭状癌と非乳頭状癌 の形態を，1）細胞分化，2）基底膜との連絡，3）基底 膜の発達の 3 点について比較し, 両者における細胞構 築の特徵を追求してみた。

\section{対象と方法}

被検対象は正常尿管 2 例と膀胱癌11例で, 正常尿管 は腎癌摘出時に標本を採取し, 膀胼癌は膀羘全摘術 7 例, 膀胱部分切除術 3 例, ならびに経尿道的生検 1 例 によって標本を採取した。

摘出標本は軽く伸展した状態で2.5\%glutraraldehyde $/ 0.1 \mathrm{M}$ cacodylate buffer 液 $\left(4{ }^{\circ} \mathrm{C} \mathrm{pH} 7.4\right)$ で 約 10 分間固定した。電䫓用標本は, 腫湯の一部とその 周囲組織を切り出し，さらに同液で 4 時間固定し， 0.1 M cacodylate buffer 液で12時間洗浄した。次に，1\% $\mathrm{OsO}_{4} / 0.1 \mathrm{M}$ cacodylate buffer 液で 2 時間後固定して から ethanol で順次脱水し, propylene oxide で置換 後, epon 樹脂に包埋した. 光顥用標本は, 摘出標本全 体を $10 \%$ formalin で 3 日間追加固定してから，切り出 し, $100 \%$ ethanol で脱水後, paraffinに包埋した. 組織診用標本は, paraffin block から厚さ $3 \mu \mathrm{m}$ で薄 切し, hematoxyline and eosin 染色標本を作製した。 組織型はすべて移行上皮癌で, 乳頭状癌 6 例, 非乳頭 状癌 5 例, 異型度は G1 2 例, G2 4 例, G3 5 例で, 深 達度は $\mathrm{pTa} \sim \mathrm{pT}_{1} \mathrm{~b} 7$ 例, $\mathrm{pT}_{2} \sim \mathrm{pT}_{4} 4$ 例であった。

電顕標本は epon block から厚さ $0.05 \mu \mathrm{m}$ の超薄切 片を作成して uranyl acetate-lead citrate で染色し, AKASHI LEM2000およびJEM-100C 透過型電子影
微鏡で観察した。

一方, 正常尿管上皮 1 例, G2乳頭状癌 2 例, G3非乳 頭状癌 2 例について，それぞれ epon 包埋 block から $0.5 \mu \mathrm{m}$ の縱断連続切片50枚を作成し, toluidine blue 染色を施して 1,000 倍光顕鏡下で観察した。乳頭状癌で は papillary frond の一部を被検対象とし, 非乳頭状癌 では主病変より連続した随伴上皮内癌を被検対象とし た.

\section{結果}

1. 正常移行上皮

（1）細胞形態の分化

正常尿管の移行上皮は $3 \sim 4$ 層の細胞から構成さ れ, 光顕下で基底膜に対して垂直な断面像（光顕縦断 面像）をみると, 半円形の基底細胞, 西洋梨状の中間 細胞，ならびに洋がさ状の表層細胞からなる三層構造 をとっていた，基底細胞と中間細胞の胞体と核は，基 底膜に垂直方向に長軸をもつ規則正しい配列を示して いた。表層細胞の核の長軸は垂直なものも小数混在す るものの大部分は基底膜に平行であった，表層および 中間細胞からは基底膜方向に向から細胞突起がしばし ば観察された. 光顕的に基底膜に平行な断面像（光顕 横断面像) では, 表層細胞は $5 \sim 6$ 角形の大型細胞と して認められ, 敷石状に密に配列していた。 中間細胞

図 1 正常移行上皮の光䫓像（緹断面），1,000倍。基 底細胞，中間細胞ならびに表層細胞が規則正しく配 列し，表層細胞からのびた細胞突起が基底膜にまで 達している (矢印)。

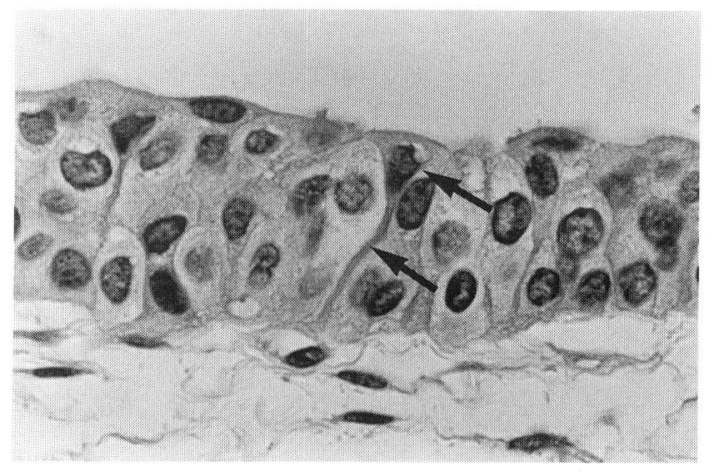


は大小の明るい胞体を持つ多角形ないし円形の細胞か らなり，基底細胞は小円形の核と多角形ないし円形の 胞体を持つ細胞として確認された。電顕像では, Golgi apparatus, telolysosomeならびに fusiform vesicle は基底細胞では余り発達していないが，中間細胞から 表層細胞へと移行するにつれて，しだいに発達してい く傾向が明らかにみられた。一方, mitochondria, roughsurfaced endoplasmicreticulum (rER), smooth-surfaced endoplasmic reticulum(sER), free ribosomeなどの細胞内小器官の発達と細胞配列との 間には関係はみられなかった。

（2）基底膜との関係

光顕縦断面像では, しばしば表層あるいは中間細胞 からのびた突起が基底膜に達しているのが観察された

図 2 乳頭状癌の電顕像 (綎断面). 乳頭状癌では表層ならびに中間細胞から 基底膜方向に微細な細胞突起がのびている (矢印).

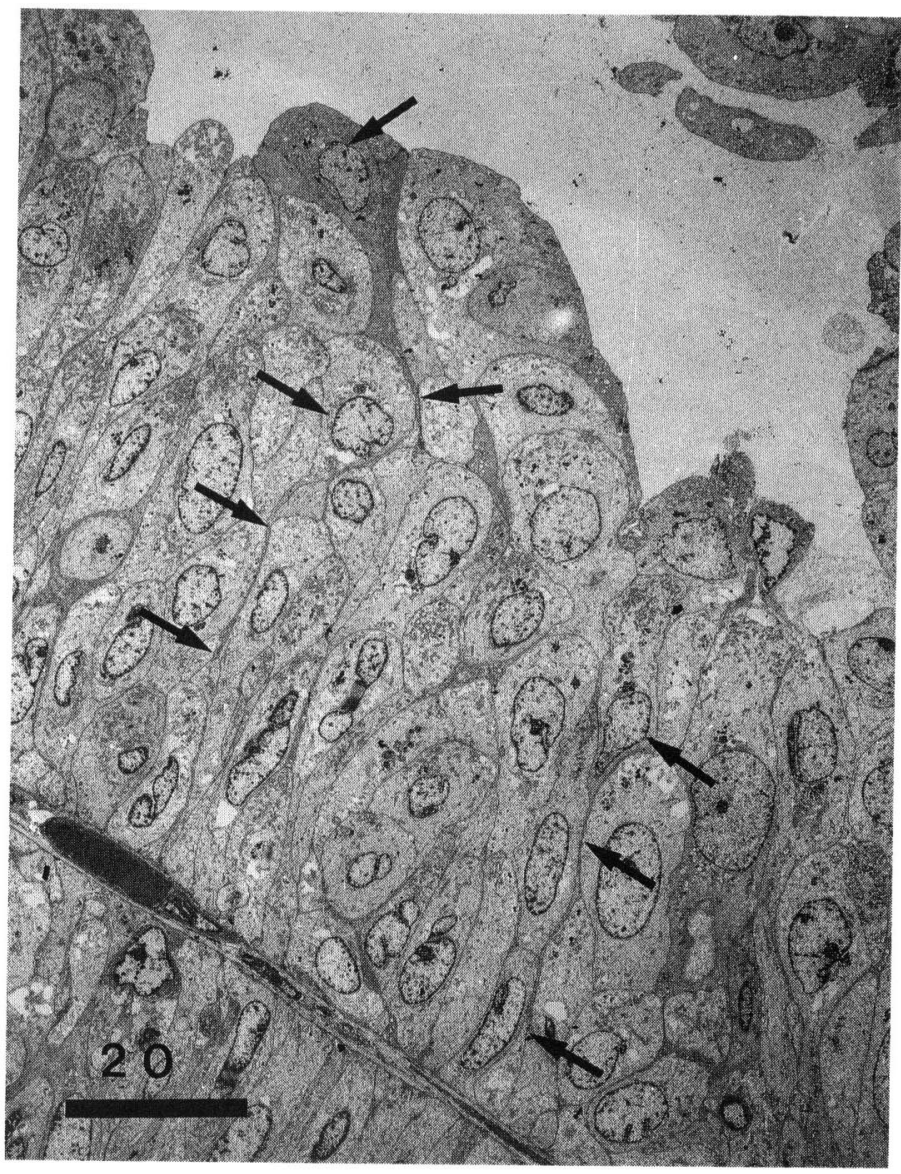

表 1 上皮細胞と基底膜との連絡頻度

標本の全上皮細胞において，基底膜との連絡を確認できた細胞数を示す。

\begin{tabular}{c|c|r|r|r|r}
\hline \multirow{2}{*}{ 部 位 } & \multirow{2}{*}{ 正常上皮 } & \multicolumn{2}{|c|}{ 乳頭 状 癌 } & \multicolumn{2}{|c}{ 非乳頭状癌 } \\
\cline { 3 - 6 } & & $\mathrm{A}$ & $\mathrm{B}$ & $\mathrm{A}$ & $\mathrm{B}$ \\
\hline 表 層 & $7 / 8(88 \%)$ & $5 / 7(71 \%)$ & $5 / 9(56 \%)$ & $0 / 12(0 \%)$ & $0 / 9(0 \%)$ \\
中間層 & $14 / 15(93 \%)$ & $14 / 19(74 \%)$ & $14 / 15(93 \%)$ & $2 / 26(8 \%)$ & $0 / 40(0 \%)$ \\
基底層 & $9 / 9(100 \%)$ & $9 / 9(100 \%)$ & $7 / 7(100 \%)$ & $10 / 12(83 \%)$ & $8 / 9(89 \%)$ \\
\hline 計 & $30 / 32(94 \%)$ & $28 / 35(80 \%)$ & $26 / 31(84 \%)$ & $12 / 50(24 \%)$ & $8 / 58(15 \%)$ \\
\hline
\end{tabular}


図 3 乳頭状癌の電顕像. 正常移行上皮之同様に, 基底細胞 basal cell (B.C.) から中 間細胞 intermediate cell (I.C.) から中間細胞 intermediate cell (I.C.), 表層細胞 superficial cell (S.C.) へと移行するにつれて Golgi apparatus (G.A.), fusiform vesicle (F.V.) ならびに telolysosome (T.L.) が発達している。 また，基底膜はよ く発達している.
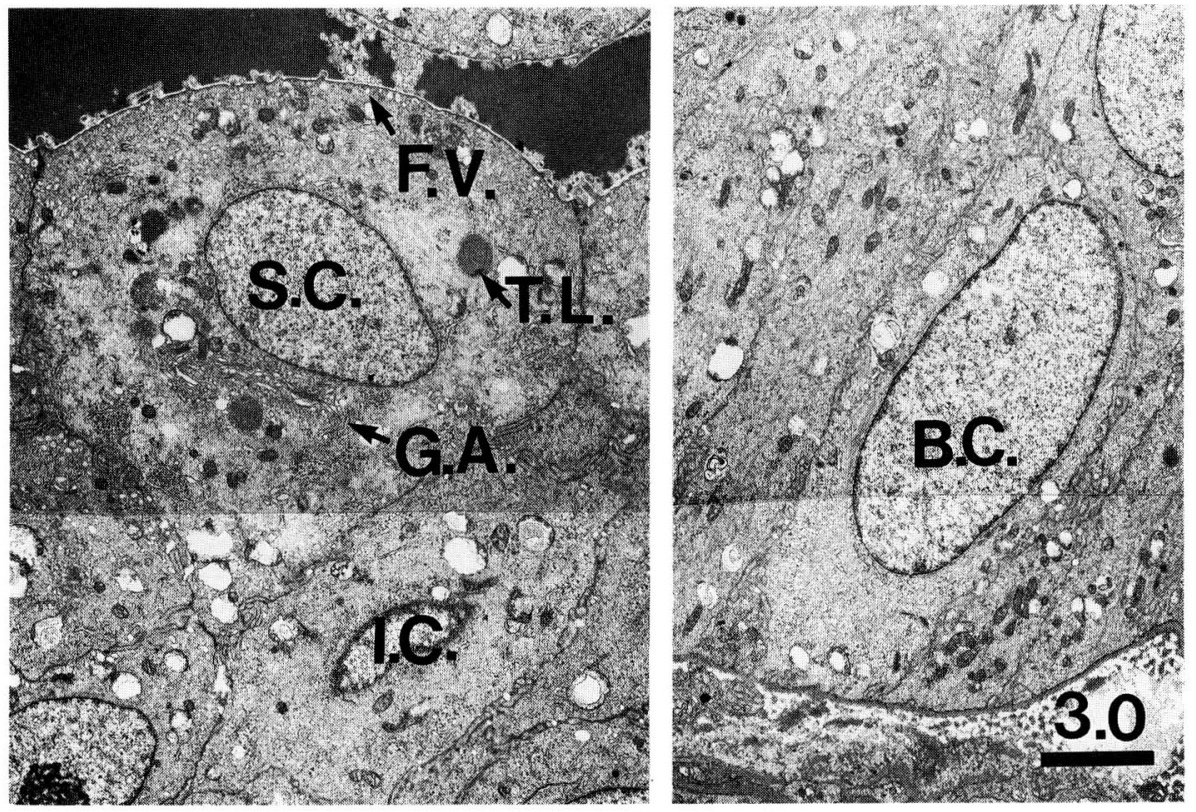

(図 1).

連続切片の観察で再構築すると，表層細胞の $88 \%$ ， 中間細胞の $93 \%$ が突起をもって基底膜と連絡してい た。基底細胞は全て直接または突起を介して基底膜と 連絡していた(表 1 ). 表層細胞では細胞突起が蛇行す る傾向があるため, 全細胞について基底膜との連絡を 追跡することはできなかった。しかし，そのような細 胞であっても連続切片のいずれかで基底膜方向に向か ら細胞突起が明瞭に認められた。

（3）基底膜

基底膜は電顕的に厚さ $0.05 \sim 0.1 \mu \mathrm{m}$ の電子密度の 高い無構造で均一な層として観察され, 基底細胞と, 中間細胞ならびに表層細胞の細胞突起との間には hemidesmosomeの形成がみられた。

\section{2. 乳頭状移行上皮癌の細胞構築}

（1）細胞形態の分化

光顕縦断面像を観察すると, G1腫瘍では半円球状の 基底細胞, 西洋梨状の中間細胞, ならびに洋がさ状の 表層細胞よりなっており，基底細胞と中間細胞の長軸 方向は基底膜に対して垂直であった，表層細胞の核の 長軸は，打打打むね基底膜に平行であった。一方，G2
腫瘍では, 基底ならびに中間細胞の形態は G1と同様に それぞれ, 半円球状ならびに西洋梨状を呈していたが， 表層細胞は洋がさ状を示すものと西洋梨状でむしろ中 間細胞に近い形態を示すものが混在してみられた。洋 がさ状を示す表層細胞の核の長軸は，基底膜に平行で あったが，西洋梨状を示す場合は垂直であった。 また， G2腫瘍では G1に比べ，極性の乱れがしばしぴみられ た、G1ならびに G2乳頭状癌では，正常上皮と同様に表 層および中間細胞からはしばしば基底膜方向に向から 細胞突起が “電顕縦断像”で観察された（図 2 ). これ は電顕横断像でみると，中間及び基底細胞の多角形な いし円形の胞体間に，より表層の細胞から基底膜方向 に向から細胞突起が小円形の胞体として観察された。

細胞内小器官を電顕縦断像で観察すると, Golgi apparatus は基底細胞では未発達だが中間細胞では核 周囲に発達し，表層細胞ではさらに発達していた（図 3 ). Fusiform vesicle \&同様に基底細胞では未発達で あり, 中間細胞さらには表層細胞では細胞壁周辺部に 良く発達していた。 また, telolysosome も基底細胞で はみられないが，表層細胞あるいは表層細胞直下の中 間細胞ではしばしば観察された。全体的に正常上皮に 
図 4 乳頭状癌の連続切片図, 1,000倍. 表層細胞からのびた細胞突起が基底膜に到達 するのが，連続的にとらえられる(矢印)。
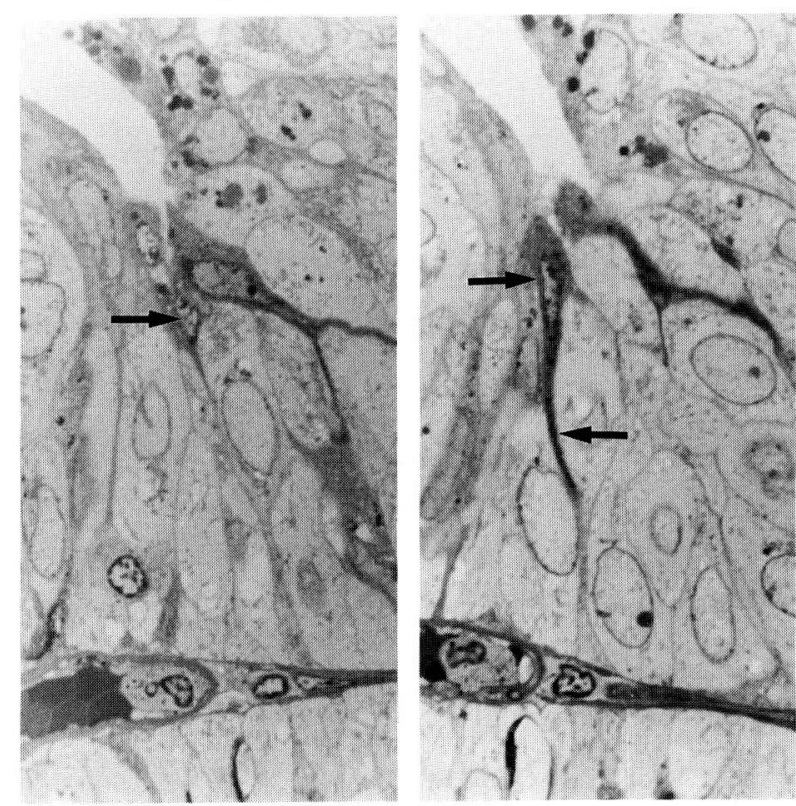

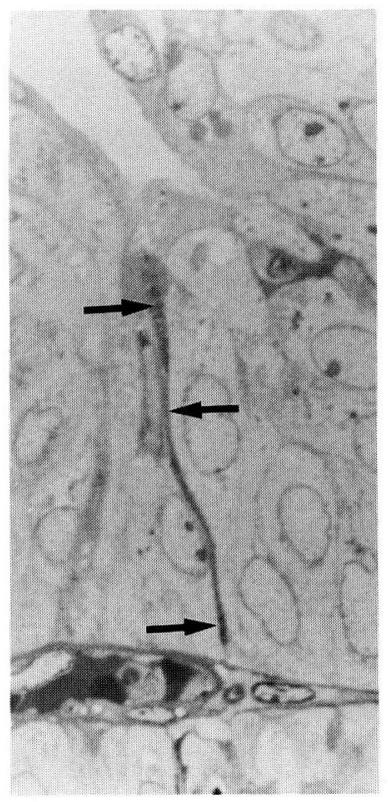

図 5 非乳頭状癌の電顕像(上皮内進展部)。細胞突起 の方向は無秩序で(矢印), 細胞内小器官の発達も不 規則である。

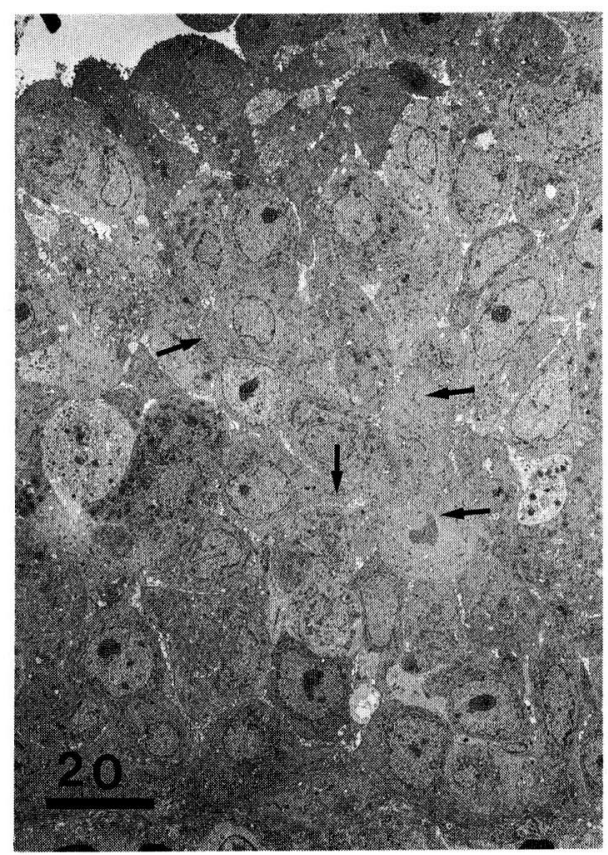

比べ, fusiform vesicle ならびに telolysosome の発達 は不良であるが，G1あるいは G2腫瘍に拈いても基底
細胞から中間，表層細胞へと向から段階的な発達は保 たれていた。ただし，G2腫瘍に掞ける洋がさ状の表層 細胞では, これらの細胞内小器官群は, ょく発達して いたが，西洋梨状の表層細胞では前者に比べ，未発達 であり, G2腫瘍の小器官群の発達は G1腫瘍に比べて 多少ばらつきがみられた。 その他の細胞内小器官には 特記するような所見は得られなかった。

（2）基底膜との関係

連続切片で検討すると，1例では表層細胞の71\%, 中間細胞の $74 \%$, 基底細胞の $100 \%$ で, 他の 1 例ではそ れぞれ $56 \%, 93 \%, 100 \%$ の細胞で直接または細胞突起 を介した基底膜との連絡を確認できた（図 4)（表 1). 正常上皮に比して細胞層が厚く，また表層細胞の極性 にやや乱れがあるため, 基底膜との連絡確認率は多少 低下していた。しかし, 表層細胞のうち, 直接基底膜 まで追跡不可能であったものであっても, 連続切片の いずれかで基底膜へ向から細胞突起が認められた。

\section{（3）基底膜}

電顕像ではすべての症例で基底膜は正常上皮と同様 に均一な層としてょく保持されており, 基底細胞ある いは中間ならびに表層細胞からの細胞突起との間に hemidesmosome が形成されていた（図 3 ).

3. 非乳頭状移行上皮癌の細胞構築

（1）細胞形態の分化 
図 6 非乳頭状癌上皮内進展部の電䫓像(基底部). 基 底部の細胞間に表層からの細胞突起はみられない。 基底膜は菲薄化あるいは断裂している. 基底部の細 胞が間質と接した面は不規則で多数の微小突起を形 成している. 基底膜の断裂部より微小突起が粘膜固 有層へ侵入している(矢印). Hemidesmosome は減 少ないしは消失している。

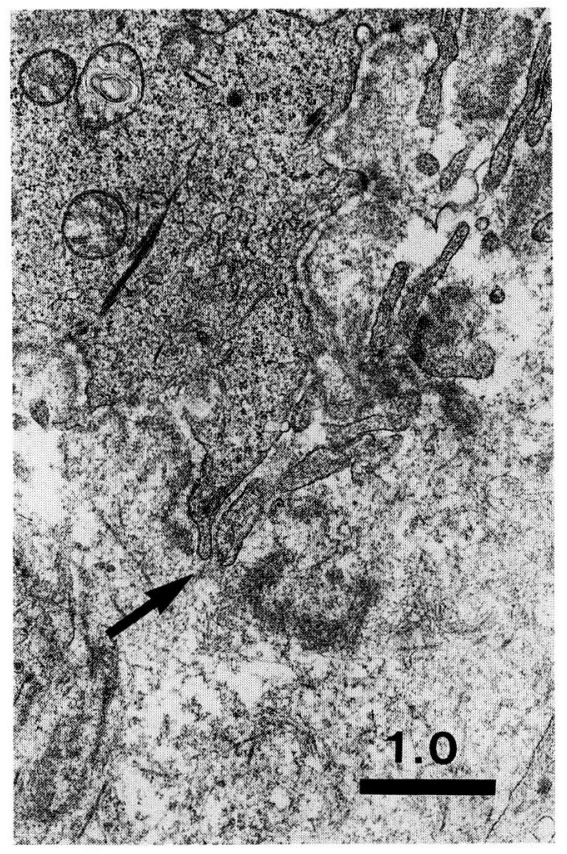

被検対象はいずれも G3で筋層へ微小胞巣を形成し ながら浸潤性に増殖していた（tentacular invasion）。 浸潤部の微小胞巣内では細胞の極性は失われており, 正常上皮と乳頭状癌に拈いてみられた基底細胞，中間 細胞ならびに表層細胞からなる規則的な細胞配列は認 められなかった。

主病巣より連続した上皮内癌部においても癌細胞の 極性は失われていた。細胞突起の発達は不十分であり， その方向も不規則であった（図 5 ). 電顕像も, fusiform vesicle, Golgi apparatus, ならびに telolysosone の発 達の程度と細胞の局在との間に関連はみられなかっ た。 た，基底部の細胞が間質と接した面では，不規 則な微小突起が多数みられた（図6）.

（2）基底膜との関係

主病変から連続した上皮内癌部の縦断連続切片によ る三次元的再構築を 2 例に扣いて試みたが，表層なら びに中間部に位置する細胞の細胞突起は未発達であ り，その方向性も不規則であるため，基底膜との連絡
が確認されたものは汪とんどなかった（表 1 ）。

（3）基底膜

主病変に連続した上皮内癌部の縦断電顕像を観察し たところ, 基底膜の形状は不均一でしばしば菲薄化し， 部位によって断裂する部分がみられた。断裂部からは 基底細胞の小突起が間質内に侵入する像が観察された （図 6 ）。また，基底膜の菲薄化した部分では hemidesmosomeの形成は不十分であった。

\section{考察}

$\operatorname{Martin}^{4) 5}$ はモルモット，また田中6)はヒトの正常尿 路移行上皮の光顕像において，それぞれ表層細胞の細 胞突起が基底膜に達しているのを観察した。さらに Petry and Amon ${ }^{7 / 8)}$ は動物ならびにヒト尿路移行上皮 の電顕所見から，表層，中間ならびに基底細胞がそれ ぞれ基底膜に直接結合していると報告している。しか し，これらの研究は標本の中で偶々とらえた所見をも とにしたすのであり，すべての上皮細胞が基底膜に連 絡していることを直接証明したものではない.

本研究では, $0.5 \mu \mathrm{m}$ の連続切片50枚を観察して再構 築を試みた。この方法によれば，中央部切片上の細胞 全てを割面で網羅し，また細胞突起が垂直方向である ならその走行を追跡することができるからである。そ

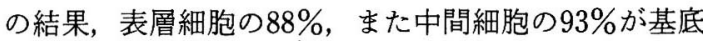
膜に細胞突起をもって直接連絡することを確認でさ た。これら細胞突起を電顕像でみると，表層ならびに 中間細胞から細長い胞体がほ潼垂に伸び，基底膜と hemidesmosomeを形成しながら結合することが確認 された，基底細胞も hemidesmosomeを形成して基底 膜と直接接触していた。な抏，表層ならびに中間細胞 のうち，約 $10 \%$ では基底膜との連絡を追跡できなかっ たが,これは $0.5 \mu \mathrm{m}$ の連続切片といら技術的限界によ るものであろう。これらの細胞であっても基底膜方向 に向から明確な細胞突起を形成していたことは，基本 的には正常移行上皮細胞が全て基底膜と連絡している ことを強く示唆している。

一方, 細胞内小器官の $5 ち$ Golgi apparatus, fusifor$\mathrm{m}$ vesicle ならびに telolysosome は，いずれも基底細 胞から中間ならびに表層細胞へと移行するにつれてし だいに発達する傾向がみられた。 Golgi apparatusは 細胞膜の産生に関与し，細胞膜の胞体内陥入部である fusiform vesicleは細胞の伸展弛緩に対応して，その 数を増減する11)。 また, telolysosome は細胞内に蓄積 された小器官の自己消化物あるいは老廃物が加水分解 されたものである。これらの細胞内小器官が基底細胞 
から表層へ移行するほどよく発達してみられるという ことは, 移行上皮細胞の基底細胞から中間, 表層細胞 への分化を反映するものと解釈されている ${ }^{10) \sim 12)}$. 従っ て以上の自験所見を総括するなら，七ト正常尿路移行 上皮は細胞突起をもって基底膜との連絡を保ちつつ, 基底細胞から中間細胞さらには表層細胞へと形態を変 えながら分化した構造をもつとみなされる。

乳頭状癌は基底細胞, 中間細胞ならびに表層細胞よ りなる配列を示し, 上記三種の細胞内小器官も基底細 胞から表層細胞へと移行するにつれて発達するのが観 察された。中間ならびに表層細胞は基底膜方向への細 胞突起を有しており, 過半数の表層細胞ならびに大部 分の中間細胞の細胞突起が基底膜に直接達しているの が連続切片による検索で確認された。また基底膜もよ く保持され，正常上皮との差はみられなかった。すな わち, 乳頭状癌には基底膜との連絡を保ちつつ基底, 中間ならびに表層細胞へと分化成熟していく規則性が みられ, 正常尿路移行上皮の細胞構築を基本的に保持 していると考えられる。

G2移行上皮癌には heterogeneity の傾向があり，こ れが G2腫湯の位置づけを瞹昧にしていると思われ $ろ^{3)}$. 連続切片作成の対象とした乳頭状癌 2 例は G2腫 瘍であるが，表層細胞の $29 \sim 44 \% て ゙$ 細胞突起を基底膜 まで追跡することができなかった。これらの細胞もす べて基底膜に突起をもって連絡してはいるが, cellurality が高く, あるいは突起が腫場細胞の極性の乱れと ともに蛇行しているため, その走行を基底膜まで追跡 できなかったとする見方も否定できない，しかし，乳 頭状癌では基底膜に連絡しない細胞が実際に存在する 可能性もある。すなおち，乳頭状癌では基底細胞のみ ならず中間細胞にも核分裂像をみることがあるが，こ れらの中間細胞から直接分裂した細胞は基底膜との連 絡を本来失っているはずである，ともあれ，表層細胞 と基底膜との連絡がかなりの頻度で確認できなかった ことは, G2乳頭状癌の heterogeneity を細胞構築の面 から説明するものと考えられる。

一方, 非乳頭状癌にあっては浸潤小胞巣部ならびに 主病巣から連続した上皮内癌に拈いて, 細胞の極性と 細胞突起の方向は無秩序であり, かつ細胞内小器官の 発達した細胞と未発達な細胞が不規則に分布してい た. 上皮内癌部の連続切片では, 基底膜から隔たった 部位にある癌細胞と基底膜の間に連絡はみられなかっ た。 また, 同部の基底膜はしばしば菲薄化ないしは断 裂して招り，断裂部からは微小突起の一部が粘膜固有
層へ侵入しているのが観察された。基底膜は上皮細胞 からその基質が分泌され，線維芽細胞との共同作業に よって完成されるが13)，その存在は上皮組織の形成と 細胞分化に不可欠とされる ${ }^{13) ~ 15)}$. したがって自験所見 は，非乳頭状癌を構成する細胞が極性と分化様式の秩 序に欠け，基底膜の形成も不完全であるため，基底膜 との連絡がないままに増殖することを示するのと考学 られる。

$\operatorname{Koss}^{16)}$ は，1）浸潤癌の大部分には乳頭状癌の既往 がないこと,2）乳頭状癌と非乳頭状癌では予後が明ら かに異なること,3）乳頭状癌では周辺粘膜の異形性の 有無により浸潤癌の発生頻度が異なること,4）原発性 上皮内癌では浸潤癌の発生頻度が高いこと,5）膀脱上 皮癌を mapping とする，しばしば潜在浸潤癌が発見さ れること，また，6）乳頭状癌の浸潤は broad front pattern を主体とするのに対し，非乳頭状癌の浸潤は tentacular invasion を呈することを指摘している。す なわち，これは同じ尿路移行上皮癌であっても，乳頭 状癌と非乳頭状癌は本質的に性格の相異なる腫瘍であ ることを示唆している. 本研究は, 正常尿路移行上皮 の細胞構築が乳頭状癌では基本的に保持されているの に反して，それが非乳頭状癌では上皮内に留まる部分 でも既に失われていることを示した。この両者間の相 違は，抢そらく発癌過程の早期で発見されるものでは なかららか. 乳頭状癌ならびに非乳頭状癌におけるこ のような細胞構築の基本的な特徵が, 形態学的には発 育様式として, また生物学的には悪性度（予後）の差 として反映すると考えられる。

\section{結 語}

1. 正常尿路移行上皮は $0.1 \sim 0.2 \mu \mathrm{m}$ の均一な基底 膜上に，それぞれ特徵的な形態をとる基底細胞，中間 細胞ならびに表層細胞からなる三層構造をとり, 分化 成熟度を示す細胞内小器官群は基底細胞から表層細胞 へ移行するにつれてょく発達していた。これら各細胞 は規則的な極性をもち，直接または細胞突起を介して 基底膜と連絡しており，これが正常上皮に特徵的な細 胞構築であるとみなされた。

2. 乳頭状癌は基本的には正常上皮と同様の細胞構 築をとり，基底膜もよく保持されていた。しかし，G2 腫瘍の表層細胞の中には極性の乱れや基底膜との連絡 が確認されないものも混在しており，これは heterogeneityを示す所見と考学られた。

3. 非乳頭状癌には細胞の極小と分化に規則性が認 められなかった。主病巣から連続した上皮内癌に拈い 
ても基底膜との連絡をもつ細胞はほとんど認められ ず, 基底膜の発達は不完全でしばしば菲薄化し, 断裂 していた。 また基底部の細胞の不規則な微小突起の一 部が基底膜の断裂部から粘膜固有層へ侵入する像をみ た.

4. 乳頭状癌と非乳頭状癌における上述の如き細胞 構築の差は発癌過程の初期に発現し, これが両者の発 育様式ならびに悪性度の差として反映すると考光た。

\section{文献}

1) Ashmer, P.W.: The pathology of vesical neoplasms. Its evaluation in diagnosis prognosis. $\mathrm{J}$. A.M.A., 91, 1697-1704, 1928.

2) Yamada, T., Yokogawa, M., Mitani, G. Inada, T., Ohwada, F. and Fukui, I.: Two different types of cancer development in the urothelium of the human urinary bladder with different prognosis. Jpn. J. Clin. Oncol., 5, 77-90, 1975.

3）守山正胤, 加藤哲郎, 森 久, 阿部良说, 佐藤一 成, 土田正義, 上坂佳敬, 綿貫 勤：膀胱移行上皮 癌131例の臨床病理学的検討一とくに深達度, 異型 度ならびに発育様式と予後との関連を中心に一。 日泌尿会誌，78，1940－1949，1987.

4) Martin, B.F.: The effect of distension of the urinary bladder on the lining epithelium and on its histochemical reaction for alkaline phosphatase. Annales d'Histochimie, 7, 51-62, 1962.

5) Martin, B.F.: Cell replacement and differentiation in transitional epithelium: A histological and autoradiographic study of guineapig bladder and ureter. J. Anatomy, 112, 433-455, 1972.

6) Tanaka, K.: Polarisationsoptische Analuse der Ubergangsepithelien des Menschen. Arch. histol. Jap., 22, 229-236, 1962.

7) Petry, G. and Amon, H.: Licht-und elektronenmikroskopische Studien über Struktur und Dynamik des Ubergangsepithels. Z. Zellfor- sch., 69, 587-612, 1966.

8) Petry, G. and Amon, H.: Die funktionelle Struktur des Harnblasenepithels und ihre Bedeutung für die urologische Cytodiagnostik. Klin. Wschr., 44, 1371-1379, 1966.

9) Hicks, R.M.: The mammalian urinary bladder an accomodating organ. Biol. Rev., 50, 215-246, 1975.

10) Fulker, M.J., Cooper, E.H. and Tanaka, T.: Proliferation and ultrastructure of papillary transitional cell carcinoma of the human bladder. Cancer, 27, 71-82, 1971.

11) Pauli, B.U., Alroy, J. and Weinstein, R.S.: The Ultrastructure and pathobiology of urinary bladder cancer. In The Pathology of Bladder Cancer Volume 2, p. 41-140, CRC Press, Inc. Boca raton, Florida, 1983.

12) Tannenbaum, M.: Ultrastructural pathology of the human urinary bladder. In Diagnostic Electron Microscopy Volume 2, p. 221-267, John Wiley \& Sons Inc., New York, 1979.

13）梶川欽一郎：結合組織, 第 1 版, 373-374, 金原出 版, 東京, 1984 .

14) Blümcke, S., Rode, J. and Niedorf, H.R.: Formation of the basement membrane during regeneration of the corneal epithelium. Z. Zellforsch., 93, 84-92, 1969.

15) Banerjee, S.D., Cohn, R.H. and Bernfield, M.R. : Basal lamina of embryonic salivary epithelia production by the epithelium and role in maintaining lobular morphology. J. Cell Biol., 73, 445-463, 1977.

16) Koss, L.G.: Tumors of the urinary bladder, Atlas of tumor pathology, Supplement, Fascile 11, Second Series, p. S-24-S-25, AFIP, Washington, D.C., 1984.

（1989年 3 月 14 日受理） 